\title{
BIOPOLYMERS APPLIED TO REMOVE METAL IONS THROUGH ULTRAFILTRATION. A REVIEW
}

\author{
JULIO SÁNCHEZ ${ }^{1}$, BRYAN BUTTER ${ }^{1}$ AND BERNABÉ L. RIVAS ${ }^{2 *}$ \\ ${ }^{\text {I} D e p a r t a m e n t o ~ d e ~ C i e n c i a s ~ d e l ~ A m b i e n t e, ~ F a c u l t a d ~ d e ~ Q u i ́ m i c a ~ y ~ B i o l o g i ́ a, ~ U n i v e r s i d a d ~ d e ~ S a n t i a g o ~ d e ~ C h i l e, ~ U S A C H, ~ S a n t i a g o, ~ C h i l e . ~}$ \\ ${ }^{2}$ Polymer Department, Faculty of Chemistry, University of Concepción, Concepción, Chile.
}

\begin{abstract}
This manuscript is an overview of the versatile biopolymer materials alginic acid, carboxymethyl cellulose, and quaternized chitosan which contain different functional groups to remove hazardous inorganic species. These bioadsorbents are completely water-soluble and have a high versatility to achieve a higher sorption capacity and efficiency under different experimental conditions in combination with ultrafiltration membranes through the liquid-phase polymer-based retention (LPR) technique. In general, thesebioadsorbents are friendly with the environment and have a higher biodegradability compared with those more employed synthetic polymers.
\end{abstract}

Keywords: Biopolymers, Ultrafiltration membranes, Metal ions, Removal.

\section{INTRODUCTION}

\subsection{General aspects on the water-contamination}

Water is uniquely vulnerable to pollution. Known as a "universal solvent," water is able to dissolve more substances than any other liquid on earth. Two billion people around the world rely on health care facilities that do not have any safe water. Availability of fresh water, the nature's gift controls the major part of the world economy. The adequate supplies of water are necessary for agriculture, human consumption, industry as well as recreation. It is a well known fact that fresh water is an important necessity for our health. With the advancement of technology and industrial growth, fresh water resources all over the world are threatened. One-sixth of the world population suffers from the freshwater unavailability situation. It is also why water is so easily polluted. Toxic substances from farms, mining, towns, and factories readily dissolve into and mix with it, causing water pollution [1].

Water pollution occurs when unwanted materials enter in to water, changes the quality of water and harmful to environment and human health [2-3]. Being a universal solvent, water is a major source of infection. According to world health organization (WHO) 80\% diseases are water borne. Drinking water in various countries does not meet WHO standards [4]. 3.1\% deaths occur due to the unhygienic and poor quality of water [5]. Discharge of domestic and industrial effluent wastes, leakage from water tanks, marine dumping, radioactive waste and atmospheric deposition are major causes of water pollution. Toxins in industrial waste are the major cause of immune suppression, reproductive failure and acute poisoning. Infectious diseases, like cholera, typhoid fever and other diseases gastroenteritis, diarrhea, vomiting, skin and kidney problem are spreading through polluted water [6].

It is reported that 75 to $80 \%$ water pollution is caused by the domestic sewage. Waste from the industries like, sugar, textile, pulp, electroplating, pesticides, and paper are polluting the water [7]. Polluted river have intolerable smell and contains less flora and fauna. $80 \%$ of the world's population is facing threats to water security [8]. Different industrial effluent that is drained in to river without treatment is the major cause of water pollution. Hazardous material discharged from the industries is responsible for surface water and ground water contamination.

Nevertheless, one of the more hard water contaminants are attributed to metals that disposed off and industrial waste can accumulate in lakes and river, proving harmful to humans and animals. Toxic metals enter into water and reduced the quality of water [9]. $25 \%$ pollution is caused by the industries and is more harmful.

\subsection{General aspects on "heavy metals"}

Although there is no specific definition of a heavy metals, literature has defined it as a naturally occurring element having a high atomic weight and high density which is five times greater than that of water [10]. Among all the pollutants, "heavy metals" have received a great attention to environmental chemists due to their toxic nature. Heavy metals are usually present in trace amounts in natural waters but many of them are toxic even at very low concentrations [11]. Metals such as arsenic, lead, mercury, cadmium, nickel, chromium, cobalt, zinc, and selenium are highly toxic even in low quantity. Increasing quantity of heavy metals in our resources is currently an area of greater concern, especially since a large number of industries are discharging their metal containing effluents into fresh water without any adequate treatment [12].

Heavy metals become toxic when they are not metabolized by the body and bioaccumulate in the soft tissues. They may enter the human body through food, water, air or absorption through the skin when they come in contact with humans in agriculture, manufacturing, pharmaceutical, industrial or residential settings. Industrial exposure accounts for a common route of exposure for adults. Ingestion is the most common route of exposure in children. Natural and human activities are contaminating the environment and its resources, they are discharging more than what the environment can handle. [13]

According to different ways to refer to heavy metal, IUPAC [14] established the following: "Over the past two decades, the term "heavy metals" has been used increasingly in various publications and in legislation related to chemical hazards and the safe use of chemicals. It is often used as a group name for metals and semimetals (metalloids) that have been associated with contamination and potential toxicity or ecotoxicity. At the same time, legal regulations often specify a list of "heavy metals" to which they apply. Such lists may differ from one set of regulations to the other, or the term may be used without specifying which "heavy metals" are covered. In other words, the term "heavy metals" has been used inconsistently. This has led to general confusion regarding the significance of the term. There is also a tendency to assume that all so-called "heavy metals" have highly toxic or ecotoxic properties. This immediately prejudices any discussion of the use of such metals, often without any real foundation. The inconsistent use of the term "heavy metals" reflects inconsistency in the scientific literature. It is, therefore, necessary to review the usage that has developed for the term, paying particular attention to its relationship to fundamental chemistry. Without care for the scientific fundamentals, confused thought is likely to prevent advance in scientific knowledge and to lead to bad legislation and to generally bad decision-making". Therefore, the term "heavy metal", because it is often used with connotations of pollution and toxicity, is probably the least satisfactory of all the terms quoted as it leads to the greatest confusion. "Heavy" in conventional usage implies high density. "Metal" in conventional usage refers to the pure element or an alloy of metallic elements. Knowledge of density contributes little to prediction of biological effects of metals, especially since the elemental metals or their alloys are, in most cases, not the reactive species with which living organisms have to deal. Due to that, in the current review we will refer as metal contamination.

Contamination for metals is one of the most widespread environmental concerns threatening human health and ecosystems because of their recalcitrance and persistent nature in the environment and high water solubility, facilitating 
environmental mobilization or even bioaccumulation. [15] Moreover, everincreasing industrial development and the use of several pesticides in agriculture have been worsening this environmental pollution scenario over time. The discharged heavy metal ions that are difficult to be degraded into cleaning products, being as a part of the food chain, accumulate into living organisms and eventually cause serious health issues even at extremely low concentrations.

The World of Health Organization, WHO established that the highest concentration of metal ions in water should be in a range of 0.01-1 ppm [16], however, metal ion concentrations up to $450 \mathrm{ppm}$ are currently reported in effluents.

\subsection{Procedures to remove metal ions}

Because of the toxicity of metals released into the environment, there has been an increase in the number of studies concerning removal of metals from aqueous solutions. Also, from the point of view of resource recovery, the removal and recovery of metals is extremely important as metals are non-renewable. Presently, there are many methods that are being used to remove and recover metals from the environment like ion-exchange, solvent extraction, chemical precipitation, nanofiltration, reverse osmosis, electrochemistry, and adsorption. [17-38]

Among these techniques, adsorption is generally preferred due to its high efficiency, low cost possibilities, easy handling, and also the availability of different adsorbents, however, most of these conventional methods are noneconomical and have many disadvantages such as incomplete metal removal, high energy requirements, and generation of toxic sludge or other waste products that require disposal or treatment noted that selective separation of heavy metal ions from water facilitates environmental protection and the reuse of a specific target precious heavy metals. However, most of the conventional methods applied are nonspecific and exhibit low selectivity. It is also known that the degree and extent of toxicity of metals differ considerably from one metal to the other. Selective removal methods are therefore required to separate these metals from wastewater. Therefore, there is a need to develop novel adsorbents which have high selectivity. According to that the liquid-phase polymer-based retention, LPR, technique has emerged as a technique with a great advantage since is carried out in homogeneous media avoiding the phenomenon of mass transfer or diffusion that occurs in heterogeneous medium and low energy costs.[39-42] To carry out the removal process through LPR, one of the requirements is a water-soluble polymer which can be synthetic, biopolymer, or artificial. In this review, we will present and discuss the metal ion removal properties by LPR technique including biopolymers and artificial polymers.

\subsection{Biopolymers and artificial polymers to remove contaminant metal ions}

According to IUPAC the term of biopolymer corresponds to Macromolecules (including proteins, nucleic acids, and polysaccharides) formed by living organisms.[43]

Some of these have been used directly or modified arising artificial polymers to remove contaminant metal ions. It is due some properties like water-solubility, lower toxicity, and lower cost compared with those synthetic adsorbent polymers.

Biosorption arises as an alternative that draws attention to the removal of metal ions in industrial effluents, since it is a technology that allows not only to remove them, but also, to treat agricultural waste that previously had no useful, in addition, these biosorbent materials are low cost and easy acquisition. [44-45] Among the advantages of biosorption compared to conventional techniques is: low cost, high efficiency, minimization of chemicals and biological sludge, no additional nutrients are required, regeneration of biosorbents, and possibility of metal recovery. However, despite the advantages of this metal removal method, it is still in its research stage and has not been transferred technological knowledge, for this reason it has not currently been implemented at the industrial level. [46-47]

Biosorbents are materials from microbial flora, algae, plants, residual biomass, agro-industrial products or some biopolymers, these must be able to directly adsorb the metal ion as ion form from the solution. Biomaterials undergo simple, low-cost physicochemical treatments. In order to improve their adsorption capacity in application processes such as metal removal or recovery of metal species in solution. [48-49]
The quality of the biosorbent is linked to the amount of adsorbate it can attract and retain; in this sense, the search for new low-cost biosorbent materials with great potential for adsorption of metal ions present in non-dual waters, has become the main objective of science. The reason why, various studies have been carried out evading the effectiveness of many microbiological, plant and animal biomasses, as well as various products derived from their physical pre-treatment and chemical modification. [46]

Biosorption is a process that began in the early 1990s to remove pollutants from wastewater from the industrial sector. Subsequently, research has focused mainly on the use of live and/or dead biomass. However, the results shown in the literature present as a better alternative the materials derived from dead biomass, due to their economic and maintenance advantages, it is emphasized that the use of dead biomass avoids the supplement of nutrients and eliminates the problem of toxicity, in addition, the adsorption process is not interrupted by the death of the biomass due to the high concentrations of pollutants inside them.

In the current review the focus will be the adsorption of divalent metal ions by biopolymers like alginic acid and those modified (artificial) from cellulose and chitin.

Alginic acid is unbranched glycuronan composed of $\beta$-d-mannuronic acid (Mblock), $\alpha$-l-guluronic acid (G-block), and alternating sequences of both $\beta$ - $d$ mannuronic and $\alpha$-l-guluronic acid (MG-block). This biopolymer has carboxylic acid as active groups to interact with metal ions. Alginate is a linear polysaccharide that is produced by the bacterial Pseudomonas and Azotobacter and by marine algae. The physicochemical properties of alginate have led to its ubiquitous use as an additive in the food industry, and its role in bacterial adherence, colonization, and survival in infections has attracted a great deal of attention from biomedical researchers.

Cellulose, the most abundant biopolymer available, would also be interesting as a polymer component, but the low solubility of cellulose in essentially al conventional solvents severely limits the use and application of cellulose in bioinspired hybrid materials. As a result, numerous studies have explored the direct mineralization of insoluble or slightly swollen cellulose scaffolds Moreover, several research groups studied the mineralization of different types of cellulose [50-53], but the overarching problem in these approaches is the limited solubility of the cellulose, which leads to materials that are mostly surface-mineralized but not throughout the cellulose matrix. Thus, there is a need to develop protocols for a more intimate connection between the cellulose matrix and the calcium phosphate formed during mineralization. Two obvious strategies are available: (i) modify the cellulose such that it becomes water-soluble or (ii) use solvents that provide a molecular dissolution of cellulose, such as ionic liquids. In the current review the interest will be the use of water-soluble derivatives.

Carboxymethyl cellulose (CMC), which has a higher water-solubility than native cellulose, has been used for the synthesis of calcium phosphate nanoparticle/CMC composites for dental repair. [54] Salama, et al. studied the mineralization of $\mathrm{CMC} / \mathrm{silica}$ hybrids. [55] However, besides a few watersoluble cellulose derivatives that are available on a commercial scale, the number of specific and tailor-made additives for calcium phosphate precipitation is still rather limited. This is interesting because calcium phosphate mineralization control or delivery of (polymer stabilized) calcium phosphate nanoparticles are interesting for e.g., dental repair (remineralization), tooth pastes, or drug or gene delivery. [56-58] As a result, although the amounts of polymeric additive needed for an individual application are not very large, the overall need for a special polymer may still be rather large, considering that toothpastes and mouthwash products for dental protection are an ever growing market.

Chitin is a polymer obtained from the waste by-products remaining in edible crustaceans such as shrimps and crabs. Chitosan is obtained from chitin and both are not always pure. The chitosan often consists of about $20 \%$ of the $\mathrm{N}$-acetyl glucosamine sugar residues of chitin while chitin often consists of about $20 \%$ of the glucosamine residues of chitosan. Chitosan and chitin biopolymers are relatively water insoluble until they are broken down into oligomers with 7 degrees of polymerization. The chitosan polymers longer than this become water soluble in solutions of $\mathrm{pH} \leq 7$. [59-60] Physical properties of the chitosan polymer exert significant influence on its biological properties. The chitosan must be properly dissolved to influence and display its antimicrobial and other biological 
activities like postharvest shelf-life enhancing properties. The physical structure of both cellulose and chitosan are based upon the $\beta-1,4$ linkages. The chitosan solution can be dried as transparent sheets, which look like cellophane. The chemical nature and biological properties of chitosan are different from chitin and cellulose polymers due to the presence of the amino groups, which are capable of binding with positively charged molecules.

The diverse biological activity of this polymer has been demonstrated by a vast number of assays conducted in animals and a few clinical studies in humans. Therapeutic applications have been proposed for chitosan because of its properties such as antioxidant activity, cholesterol, and triglyceride trapping, and antibacterial and hypoglycemic effects for the prevention and treatment of chronic diseases.

The polycationic nature of chitosan also allows explaining chitosan analgesic effects. Now, to explain chitosan biodegradability, it is important to remember that chitosan is not only a polymer bearing amino groups, but also a polysaccharide, which consequently contains breakable glycosidic bonds. Chitosan is actually degraded in vivo by several proteases, and mainly lysozyme, and it is biocompatible, biodegradable, and non-toxic, so that it can be used as medical applications as antimicrobial and wound healing biomaterials. It used as chelating agent due to its ability to bind with cholesterol, fats, proteins and metal ions. [61]

Its molecular weight is typically between $300-1000 \mathrm{kDa}$ depending on the source of chitin. After cellulose, chitin is the second abundant natural polymer in the world [61-63] and it is commonly found in invertebrates as crustacean shells or insect cuticles but also in some mushrooms envelopes, green algae cell walls, and yeasts. [64-65].At industrial scale, the two main sources of chitosan are crustaceans and fungal mycelia; the animal source shows however, some drawbacks as seasonal, of limited supplies and with product variability which can lead to inconsistent physicochemical characteristics. [66-67] Table 1 shows the molecular structures of the biopolymers described above.

Table 1. Molecular structure of Biopolymers.

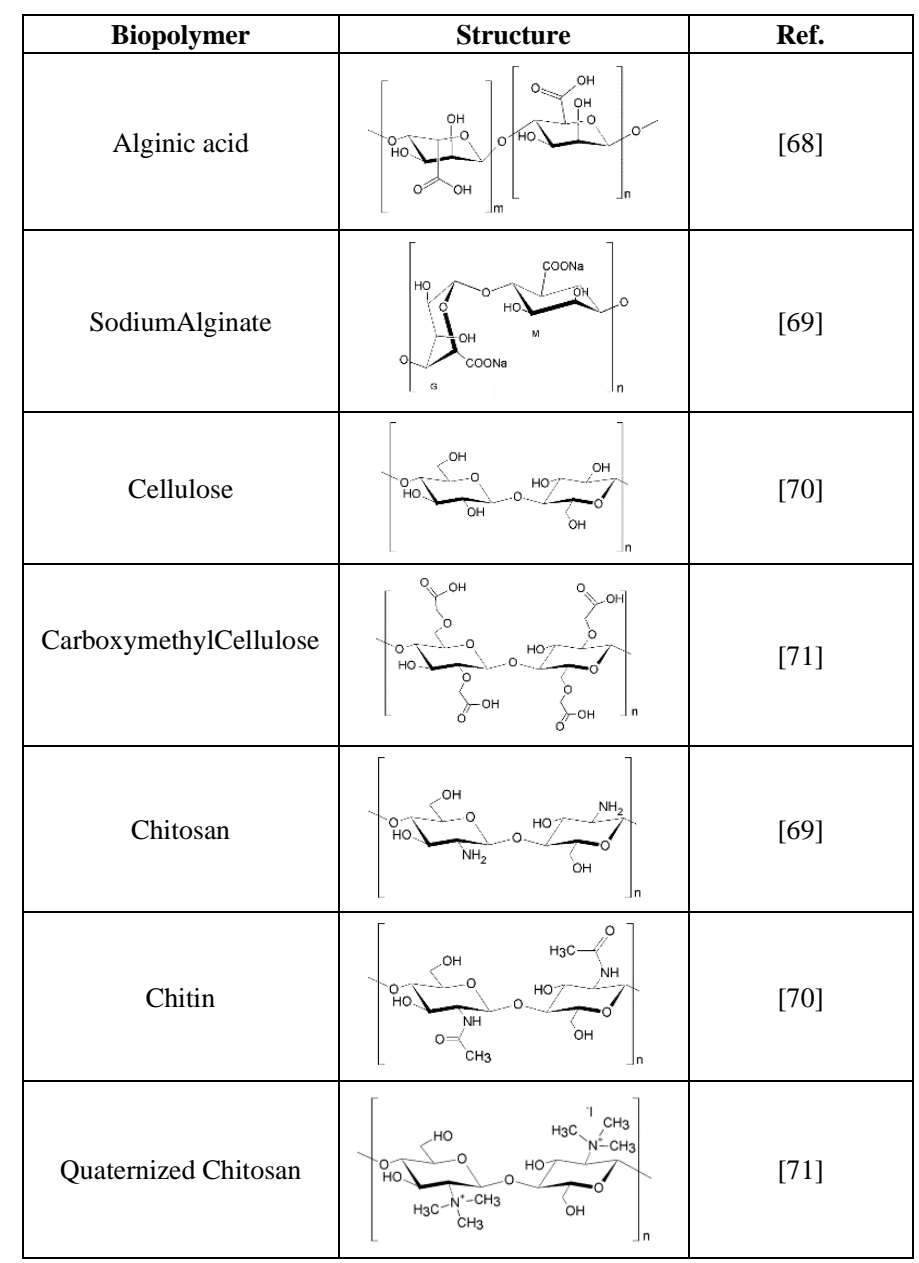

\section{LIQUID-PHASE POLYMER BASED RETENTION, LPR, TECHNIQUE}

\subsection{General principles of LPR}

Ultrafiltration normally refers to the membrane separation process that can retain solute molecules with sizes in the order of $100 \mathrm{~nm}$. Bacteria, colloids, and macromolecules in the molecular weight range of $1-300 \mathrm{kDa}$ can be retained by ultrafiltration membranes [73-75]. Pollutants of small sizes (e.g., metal ions, organic compounds like dyes, antibiotics, etc.) can be filtrated with ultrafiltration under normal operating modes.

One way to modify the UF operation to make the retention of small inorganic or organic solute molecules work is to add a water-soluble polymer, WSP that can "bond" the small solute molecules, to the feed solutions. It is well known that heavy metals in aqueous solutions can usually interact with such ligands as in chelating polymers to form complexes or functional groups as in ion exchange polymers to exchange cations or anion contaminants. The metal ions with empty orbits surrounded by the ligands are electron acceptors, and the ligands with free electron pairs will act as electron donors, thereby forming a coordination covalent bond. The bond strength between the metal ions and ligand groups increases as the electron-accepting ability of the metal ion increases. Watersoluble polymers with functional groups that can donate electron pairs can thus be exploited to induce the ligand-metal coordination. Moreover, to the chemical coordination, electrostatic forces also exist between cationic polyelectrolytes and positively charged metal ions. The interactions between organic contaminants and ligands may also involve other mechanisms. All these interactions that help bond the small solute molecules can be used to enhance the rejection of small sized solutes by ultrafiltration process.

The WSP used in LPR are normally polymer ligands with a high concentration of functional groups on the polymer chains [76]. They can easily remove the metal ions or organic contaminants via various interactions to form macromolecular complexes.

The molecular weight of the WSP should be greater than the molar mass cut-off, MMCO, of the ultrafiltration membrane in order to retain the small sized solutes bonded in the macromolecular complexes [76]. Fig. 1 is a schematic illustration of the process [77]. As one may expect, the stronger the interactions between the solute and the ligand polymer are, the better the performance of the LPR process will be in solute retention while permeating the solvent. Besides the operating conditions relevant to conventional UF (e.g., transmembrane pressure and temperature), other specific parameters (e.g., polymer type and dosage, $\mathrm{pH}$ and metal concentration of the feed solution) will also affect the solute rejection and solvent permeability in the ultrafiltration process through LPR technique [78].

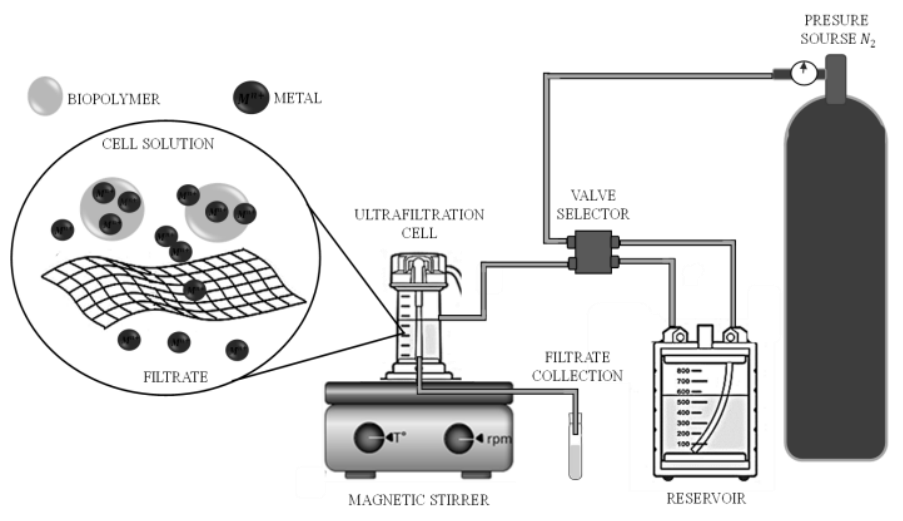

Figure 1. Scheme of the polymer-enhanced ultrafiltration, PEUF, or liquid-phase polymer based retention, LPR, system

Normally, PEUF or LPR technique can be applied by two operation methods: (1) the washing method or elution method (with the ionic strength kept constant or not) which is the most used method to study the retention capacity of a polymer in aqueous solution and is a discontinuous separation process and (2) the enrichment method or concentration method which is a continuous separation process [39-40]. In the washing method, a certain amount of polymer and small sized molecule, SSM, solutions with known concentrations are placed in the feed-side of a UF cell and a water stream is passed through the cell. [39, 40, 78]. 
For the application of the enrichment method, the WSP solution is placed in a stirred cell and a SSM solution is added continuously from a pressurized reservoir. However, when the bonding groups of the WSP are saturated by their interaction with the SSM in the solution, the maximum retention capacity (MRC) of polymer is reached and the process cannot continue [39, 40]. From this point all SSM added pass completely to retentate. Evidently, the physicochemical properties of the WSP and the polymer-metal complexes must be taken into account and their interaction with the membrane surface is also very relevant. During the retention and separation process by LPR, permeate is removed at the same rate, keeping the volume in the feed cell and the polymer concentration constant all the time [39-40].

The LPR technique can be considered as cyclic separation process and thus it should be economically more feasible when WSP, synthetic, artificial or biopolymer, can be regenerated and reused. Among regeneration methods of the WSP are the chemical methods (protolysis, transcomplexation, and redox reaction), electrochemical methods, and thermal methods. In this way, new options of regeneration of chelating groups by using new components incorporated to the system can be useful to make the process more feasible. In addition, several reviews on LPR technique have been performed [39-40] and most recently by Rivas et al. [79-80], Palencia et al. [81].

\section{REMOVAL OF METAL IONS BY BIOPOLYMERS}

\subsection{Removal of metal ions by alginic acid and alginate}

Alginate is an abundant and non-toxic natural polysaccharide, extracted from brown algae, it has carboxylate groups. It is a copolymer made of (1-4) $\alpha-1-$ guluronate $(\mathrm{G})$ and $\beta$-d-manuronate $(\mathrm{M})$ randomly linked. The main applications of this polymer are pharmaceutical and biomedical, such as the drug delivery system and cell encapsulation [82]. Alginic acid is a copolymer of two monomer units, 1,4-linked-bD-manuronic and L-guluronic acids, these are linearly arranged in hetero (MG) or homo (MM and GG) block polymers or in combination random, which largely depends on its origin [83-84]. Alginic acid and alginate possessing carboxylate groups that act as active sites under the right conditions, allows it to bind to metal ions.

Çifciand Polat [85] studied the elimination of $\mathrm{Cu}$ (II) and Fe (III).They prepared poly(vinyl alcohol) -alginic / cellulose membranes coating solutions of mixture of poly(vinyl alcohol) - alginic acid (PVA-AA) on the filter paper. They also used polyvinyl alcohol and alginic acid as extracting agents for use in polymerenhanced ultrafiltration (PEUF). It was observed that an increase in the concentration of (PVA-AA) in the solution increases retention and decreases the flow of permeate, likewise the increase in concentration of PVA-AA in the membrane has the same effect, this is because the increase of PVA-AA from the membrane, the pore size of the cellulose support decreases, and as a consequence the retention increases because it prevents the passage of metal ions bound to PVA and AA. The maximum retention of Fe (III) at an initial concentration of 1 x $10^{-4} \mathrm{M}$, was obtained with PVA of $2 \times 10^{-4} \mathrm{~g} \mathrm{~L}^{-1}$ at $\mathrm{pH} 3.0$ and pressure of 45 psi of $99 \%$, using 0.50 (w / v)\% [(75 PVA / 25 AA (w / w)] / cellulose composite membranes. The authors do not report optimal conditions for $\mathrm{Cu}$ (II).

Maureira and Rivas [86] studied the removal capacity of alginic acid (AA) through PEUF of metals $\left(\mathrm{Ag}^{+}, \mathrm{Co}^{2+}, \mathrm{Ni}^{2+}, \mathrm{Cu}^{2+}, \mathrm{Zn}^{2+}, \mathrm{Cd}^{2+}\right.$, and $\left.\mathrm{Pb}^{2+}\right) .100 \%$ removal of the mono and divalent metals was observed at $\mathrm{pH} 5.0$, at a concentration of $1.0 \times 10^{-2} \mathrm{mmol} \mathrm{L}^{-1} \mathrm{AA}$ and $2.5 \times 10^{-4} \mathrm{M}$ metal ion at constant pressure of 3.5 bar $\mathrm{N}_{2}$ in $20.0 \mathrm{~mL}$ of solution. The maximum removal capacity (MRC) was 61.67, 1.66, 2.08, 2.50, 79.1, 60.4, $49.86 \mathrm{mg} \mathrm{g}^{-1}$ at $\mathrm{pH} 7.0,7.0,7.0$, 5.0, 7.0, 7.0, 5.0 for $\mathrm{Ag}^{+}, \mathrm{Co}^{2+}, \mathrm{Ni}^{2+}, \mathrm{Cu}^{2+}, \mathrm{Zn}^{2+}, \mathrm{Cd}^{2+}$, and $\mathrm{Pb}^{2+}$, respectively.

\subsection{Removal of metal ions by cellulose and carboxymethyl cellulose}

Cellulose is the most abundant renewable resource in the world, it is a large polymer, it is made up of repeating units of $\beta$-d-glucopyranose that are covalently linked through acetal functions between the $\mathrm{OH}$ group of $\mathrm{C} 4$ and $\mathrm{C} 1$ carbon atoms ( $\beta$-1,4-glucan), its linear chain is made up of a large number of hydroxyl groups, these hydroxyl groups function as active sites, which can bind metal ions [87], carboxymethyl cellulose is a derivative of cellulose, which contains carboxymethyl groups that replace part of some hydrogen atoms of the hydroxyl groups of the cellulose skeleton [88] which like cellulose can bind to metal ions. Barakatand Schmidt [89] investigated a ultrafiltration process improved with polymers, they used carboxymethyl cellulose that is soluble in water as a complexing polymer of the cationic forms for elimination of $\mathrm{Cu}$ (II), $\mathrm{Ni}$ (II) and $\mathrm{Cr}$ (III) from the synthetic solutions of wastewater, obtaining significant retention results. For PEUF filtration, a $10 \mathrm{kDa}$ polyethersulfone membrane (FUS 0181) was used, with a pressure of 1 bar and a permeate flow of $7.5 \mathrm{~L} / \mathrm{H}$ at pH 7.0 it gave the highest efficiency, reaching 97.6 (Cu (II)), 99.1 (Ni (II)), and $99.5 \%$ (Cr (III)) and an initial concentration of $10 \mathrm{mg} \mathrm{L}^{-1}$ was used for each case. The sequence with respect to the complex capabilities of $\mathrm{CMC}$ was $\mathrm{Cu}$ (II)> $\mathrm{Cr}$ (III) $\gg \mathrm{Ni}$ (II). The membrane worked efficiently in a wide concentration range up to $100 \mathrm{mg} \mathrm{L}^{-1}$ with $\mathrm{Cu}$ (II) and $\mathrm{Cr}$ (III) ions, while the rejection efficiency of $\mathrm{Ni}$ (II) ions decreased to $57 \%$. Increasing the $\mathrm{CMC}$ ratio improved the metal bonding process. Maximum retention values were achieved with a $\mathrm{CMC} /$ metal ion ratio of 50 .

Konovalova et al. [90] studied the elimination of $\mathrm{Fe}^{2+}$ using CMC through the PEUF method. They compared the effect in PEUF with CMC with a polyvinylidene fluoride (PDVF) membrane modified with nanoparticles of magnetite, which were used as micromixers on the surface of the membrane and another one without modification, both membranes used had a molecular weight of cut $150 \mathrm{kDa}$. The PEUF experiments were carried out in an AMICON 8050 cell with no output, with constant agitation of $350 \mathrm{rpm}$ and a pressure of 100-400 $\mathrm{kPa}$. In ultrafiltration, water-soluble $\mathrm{CMC}$ polyelectrolyte was used at a concentration of $20 \mathrm{mg} \mathrm{L}^{-1}$ of $\mathrm{Fe}^{2+}$, the results obtained using the unmodified membrane was between $0.6-1.0 \mathrm{mg} \mathrm{L}^{-1}$ and with the modified membrane it was between $0.02-0.08 \mathrm{mg} \mathrm{L}^{-1}$, in the unmodified membrane it was observed that at higher pressures the flow did not increase, in concentration of CMC $0.1 \div 0.3 \%$, even a decrease in flow at a concentration of $\mathrm{CMC}$ of $0.5 \%$, for the modified membrane it was observed that the flow is linear in the concentration range of 0.1 to $0.2 \%$ and tended to a plateau of 0.3 to $0.5 \%$ of CMC respectively. The critical flux was $1.8-2.0$ times higher for the modified membrane compared to the unmodified one.

Boukary Lam et al. [91] investigated the rejection of Ni (II) through the PEUF method using two soluble polymers chitosan and carboxymethyl cellulose $(\mathrm{CMC})$ in a solution of $\mathrm{Ni}$ (II) + polymer and in a residual discharge water. They obtained excellent results using $2 \times 10^{-2} \mathrm{~mol} \mathrm{~L}^{-1}$ of polymer and $1.7 \times 10^{-5} \mathrm{~mol} \mathrm{~L}$ ${ }^{1}$ of $\mathrm{Ni}$ (II) in the presence of $2 \times 10^{-5} \mathrm{~mol} \mathrm{~L}^{-1}$ of $\mathrm{NaCl}$ at $\mathrm{pH} 7.4$ chitosan and $\mathrm{pH}$ 9.0 for $\mathrm{CMC}$ in $\mathrm{Ni}$ (II) + polymer solution, the authors did not report the elimination percentage in this experiment. The results obtained in the residual seacharge water did not show a slight increase in rejection of the metal ions (Al, $\mathrm{B}, \mathrm{Ca}, \mathrm{Co}, \mathrm{Fe}, \mathrm{K}, \mathrm{Mg}, \mathrm{Mn}, \mathrm{Na}, \mathrm{Ni}, \mathrm{S}, \mathrm{Si}, \mathrm{Sr}, \mathrm{Zn}$ ), possibly due to the competition of ions to reach the active sites of functional water-soluble polymers.

Julio Sanchez et al. [92] studied the removal of As (V) through quaternized hydroxyethyl cellulose ethoxylate (QHECE), through polymer-enhanced ultrafiltration. The authors electrochemically oxidized As (III) to As (V), using polymer (QHECE) as a support electrolyte, later the solution was taken to an ultrafiltration cell, $90 \%$ retention of As (V) was obtained, with $100 \mathrm{mg}$ of (QHECE) and $30 \mathrm{mg} \mathrm{L}-1$ of metal at $\mathrm{pH} 9.0 \mathrm{vs} 0 \%$ retention of As (III) under the same conditions, maximum retention capacity of $56 \mathrm{mg}$ As / $\mathrm{g}$ of polymer.

\subsection{Removal of metal ions by chitin and chitosan}

Chitosan is an abundantly biopolymer consisting of linear chains $(1 \rightarrow 4)$ of bound 2-amino-2-deoxy- $\beta$-D-glucopyranose, which is obtained by varying the deacetylation rate of chitin, if DA $<50 \%$, the compound can be called chitosan [93]. Chitin is a linear polysaccharide composed of (poly- $\beta$ - $(1,4)$-N-acetyl-dglucosamine), it is the second most abundant natural biopolymer [94], the presence of functional groups in the chemical structure of chitosan and chitin has allowed its study in numerous applications as an additive for water treatment, biodegradable adhesive tape sensitive to pressure, chelating agent, drug transporter, wound healing agents, in membranes, among others [95], the use of chitosan and chitin in the removal of metal ions $[96,97]$ has been studied, this is due to the presence of functional groups in the chemical structure of chitosan and chitin to interact with metal cations, due to the pair of free electrons in the nitrogen of the amino group and the presence of hydroxyl groups in the chitosan. $\mathrm{pH}$ is a critical parameter for optimization of metal ion removal, at $\mathrm{pH}$ values less than 6.0 the amino group is in protonated form and chitosan is capable of removing metals.

Mohamed KheireddineAroua et al. [98] performed $\mathrm{Cr}$ (III) and $\mathrm{Cr}$ (VI) retention studies by laboratory scale PEUF using a 500,000 MWCO polysulfone hollow fiber membrane. They simultaneously filtered solutions containing $0.05 \%$ w.t of 
chitosan as a soluble polymer and $10 \mathrm{mg} \mathrm{L}$ of each metal. The results obtained showed that at $\mathrm{pH}$ over $7100 \%$ of $\mathrm{Cr}$ (III) was retained and at $\mathrm{pH} 4,100 \%$ of $\mathrm{Cr}$ (VI) was retained, where $\mathrm{pH}$ is the main factor that controls the retention of these metals.

J. Llorens et al. [99] evaluated the removal of cadmium ions by the PEUF method using chitosan, where they filtered solutions constituted of $10 \mathrm{mg} \mathrm{L}^{-1}$ of metal and $1000 \mathrm{mg} \mathrm{L}^{-1}$ of polymer, reaching a retention efficiency of the $98.5 \%$ of the ions $\mathrm{Cd}$ (II) at a $\mathrm{pH}$ value of 7.5. The metal coordinates with two amino groups of the chitosan, giving rise to the formation of a complex. On the other hand, they observed that with the decrease of the $\mathrm{pH}$ value of the medium to 4.0, the protonation of the amino groups that leads to the release of $\mathrm{Cd}^{2+}$ occurs, allowing the reuse of the polymer.

Toledo and Rivas [100] studied the removal capacity of arsenate and chromate ions in aqueous solution using N,N,N-trimethylchitosan chloride (TMC) by means of a liquid phase polymer based retention system. The results obtained were $73 \%$ and $94 \%$ elimination with a molar ratio of $10: 1$ at $\mathrm{pH} 8.0$ for As (V) and $\mathrm{Cr}$ (VI) respectively.

Déonet al.[101] studied the removal of Se (IV) and Se (VI) using organic ultrafiltration membranes with low MWCO and ceramic membranes with higher MWCO using chitosan as pretreatment, the results obtained were an insignificant impact on selenium retention using chitosan with membranes of low MMCO ultrafiltration at $\mathrm{pH} 4.5$ or more acidic $\mathrm{pHs} \geq 3.0$ and a notable positive impact on ceramic membranes of higher MWCO reaching 95\% at $\mathrm{pH} 4.0$. Edward Kavitha et al. [102] performed a statistical design to determine the optimal conditions for removal of $\mathrm{Cu}$ (II), Ni (II) and $\mathrm{Cr}$ (VI). They used two water soluble polymers derived from chitosan, N,N,N-triethylammonium chitosan (TEAC) and carboxymethyl chitosan (CMCh). They obtained $100 \%$ removal for $\mathrm{Cu}$ (II) at pH 10.0 with a polymer ratio metal (P / M) of 3 at a concentration of $41 \mathrm{mg} \mathrm{L}^{-1}$, for $\mathrm{Ni}$ (II) $99 \%$ removal at $\mathrm{pH} 10.0$. P / M equal to 3 and an initial concentration of $35 \mathrm{mg} \mathrm{L}^{-1}$ and for $\mathrm{Cr}$ (VI) $95 \%$ removal at $\mathrm{pH} 4.0, \mathrm{P} / \mathrm{M}$ of 6 and a concentration of $43 \mathrm{mg} \mathrm{L}^{-1}$.

The table 2 includes information on the metal ion removal properties of these three water-soluble biopolymers alginic acid, carboxymethylcelullose, and chitosan. Poly(acrylic acid) (PAA), the most studied and more simple heteroatom synthetic polymer and poly(ethylenemine) (PEI)were included as comparison due to both contain the amino and carboxylic/carboxylate groups which belong to the biopolymers.

It is also very important to study and know the possible interactions between metal ions and the functional groups coming from the water-soluble biopolymers which are shown in a general way in Table 3. [103]

It is also very important to study and know the possible interactions between metal ions and the functional groups coming from the water-soluble biopolymers which are shown in a general way in Table 3.

Table 2. Summary of the performance of the biopolymers studied in the removal of metal ions.

\begin{tabular}{|c|c|c|c|c|c|c|c|}
\hline Polymer & Concentration of polymer & Metal ion & $\begin{array}{c}\text { Concentration of } \\
\text { metal ion }\end{array}$ & $\begin{array}{l}\text { Retention } \\
(\%)\end{array}$ & Membrane & pH & Ref. \\
\hline PAANa & $2 \times 10^{-3} \mathrm{~mol} \mathrm{~L}^{-1}$ & $\mathrm{Cu}^{2+}$ & $1.0 \times 10^{-3} \mathrm{~mol} \mathrm{~L}^{-1}$ & $97.0 \%$ & Cellulose & 5.0 & [103] \\
\hline \multirow[t]{2}{*}{ PAA } & $0.1 \%$ & $\mathrm{~Pb}^{2+}$ & $25 \mathrm{mg} \mathrm{L}^{-1}$ & $99.9 \%$ & Ceramic & 5.0 & [104] \\
\hline & $0.1 \%$ & $\mathrm{~Pb}^{2+}$ & $25 \mathrm{mg} \mathrm{L}^{-1}$ & $97.5 \%$ & Ceramic & 5.0 & [104] \\
\hline \multirow[t]{3}{*}{ PEI } & $150 \mathrm{mg} \mathrm{L}^{-1}$ & $\mathrm{Cu}^{2+}$ & $50 \mathrm{mg} \mathrm{L}^{-1}$ & $99.0 \%$ & PES & 6.2 & [105] \\
\hline & $0.5 \mathrm{w} / \mathrm{w}$ & $\mathrm{Pb}^{2+}$ & $200 \mathrm{mg} \mathrm{L}^{-1}$ & $90.0 \%$ & Ceramic & 5.71 & [106] \\
\hline & $0.05 \mathrm{w} / \mathrm{w}$ & $\mathrm{Cr}^{6+}$ & $10 \mathrm{mg} \mathrm{L}^{-1}$ & $99.8 \%$ & PSF & $1.0-9.0$ & [98] \\
\hline \multirow[t]{9}{*}{ Alginicacid } & $1 \times 10^{-4} \mathrm{~mol} \mathrm{~L}^{-1}$ & $\mathrm{Fe}^{2+}$ & $1.0 \times 10^{-4} \mathrm{M}$ & $99.0 \%$ & Poly(vinyl alcohol) & 3.0 & [85] \\
\hline & & $\mathrm{Cu}^{2+}$ & $1.0 \times 10^{-4} \mathrm{M}$ & & & & \\
\hline & $1 \times 10^{-2} \mathrm{mmol} \mathrm{L}^{-1}$ & $\mathrm{Ag}+$ & $2.5 \times 10^{-4} \mathrm{~mol} \mathrm{~L}^{-1}$ & $100 \%$ & R. Cellulose & 5.0 & [86] \\
\hline & $1 \times 10^{-2} \mathrm{mmol} \mathrm{L}^{-1}$ & $\mathrm{Co}^{2+}$ & $2.5 \times 10^{-4} \mathrm{~mol} \mathrm{~L}^{-1}$ & $100 \%$ & R. Cellulose & 5.0 & {$[86]$} \\
\hline & $1 \times 10^{-2} \mathrm{mmol} \mathrm{L}^{-1}$ & $\mathrm{Ni}^{2+}$ & $2.5 \times 10^{-4} \mathrm{~mol} \mathrm{~L}^{-1}$ & $100 \%$ & R. Cellulose & 5.0 & {$[86]$} \\
\hline & $1 \times 10^{-2} \mathrm{mmol} \mathrm{L}^{-1}$ & $\mathrm{Cu}^{2+}$ & $2.5 \times 10^{-4} \mathrm{~mol} \mathrm{~L}^{-1}$ & $100 \%$ & R. Cellulose & 5.0 & [86] \\
\hline & $1 \times 10^{-2} \mathrm{mmol} \mathrm{L}^{-1}$ & $\mathrm{Zn}^{2+}$ & $2.5 \times 10^{-4} \mathrm{~mol} \mathrm{~L}^{-1}$ & $100 \%$ & R. Cellulose & 5.0 & [86] \\
\hline & $1 \times 10^{-2} \mathrm{mmol} \mathrm{L}^{-1}$ & $\mathrm{Cd}^{2+}$ & $2.5 \times 10^{-4} \mathrm{~mol} \mathrm{~L}^{-1}$ & $100 \%$ & R. Cellulose & 5.0 & [86] \\
\hline & $1 \times 10^{-2} \mathrm{mmol} \mathrm{L}^{-1}$ & $\mathrm{~Pb}^{2+}$ & $2.5 \times 10^{-4} \mathrm{~mol} \mathrm{~L}^{-1}$ & $100 \%$ & R. Cellulose & 5.0 & [86] \\
\hline \multirow[t]{5}{*}{ Carboxy-methyl cellulose } & $1.0 \mathrm{~g} \mathrm{~L}^{-1}$ & $\mathrm{Cu}^{2+}$ & $10 \mathrm{mg} \mathrm{L}^{-1}$ & $97.6 \%$ & Polyethersulfone & 7.0 & [89] \\
\hline & $1.0 \mathrm{~g} \mathrm{~L}^{-1}$ & $\mathrm{Ni}^{2+}$ & $10 \mathrm{mg} \mathrm{L}^{-1}$ & $99.1 \%$ & Polyethersulfone & 7.0 & [89] \\
\hline & $1.0 \mathrm{~g} \mathrm{~L}^{-1}$ & $\mathrm{Cr}^{3+}$ & $10 \mathrm{mg} \mathrm{L}^{-1}$ & $99.5 \%$ & Polyethersulfone & 7.0 & [89] \\
\hline & $0.5 \%$ & $\mathrm{Fe}^{2+}$ & $20 \mathrm{mg} \mathrm{L}^{-1}$ & $80.0 \%$ & PDVF & 4.8 & [90] \\
\hline & $2 \times 10-2 \mathrm{~mol} \mathrm{~L}^{-1}$ & $\mathrm{Ni}^{2+}$ & $1.7 \times 10^{-5} \mathrm{~mol} \mathrm{~L}^{-1}$ & $>90.0 \%$ & Polyamide & 7.4 & [91] \\
\hline Chitosan & $2 \times 10^{-2} \mathrm{~mol} \mathrm{~L}^{-1}$ & $\mathrm{Ni}^{2+}$ & $1.7 \times 10^{-5} \mathrm{~mol} \mathrm{~L}^{-1}$ & $>95.0 \%$ & Polyamide & 9.0 & [91] \\
\hline \multirow[t]{2}{*}{ Quaternized Chitosan } & $0.1 \mathrm{~g}$ polymer in $20 \mathrm{~mL}$ solution & $\mathrm{As}^{5+}$ & $30 \mathrm{mg} \mathrm{L}^{-1}$ & $73.0 \%$ & R. Cellulose & 8.0 & [100] \\
\hline & & $\mathrm{Cr}^{6+}$ & $30 \mathrm{mg} \mathrm{L}^{-1}$ & $94.0 \%$ & R. Cellulose & 8.0 & \\
\hline \multirow[t]{8}{*}{ Chitosan } & $20 \mathrm{~mol} \mathrm{~L}^{-1}$ & $\mathrm{Se}^{4+}$ & $1.7 \times 10^{-3} \mathrm{~mol} \mathrm{~L}^{-1}$ & $95.0 \%$ & Ceramic & 4.0 & [101] \\
\hline & $20 \mathrm{~mol} \mathrm{~L}^{-1}$ & $\mathrm{Se}^{4+}$ & $1.7 \times 10^{-3} \mathrm{~mol} \mathrm{~L}^{-1}$ & $95.0 \%$ & Ceramic & 4.0 & \\
\hline & $123 \mathrm{mg} \mathrm{L}^{-1}$ & $\mathrm{Cu}^{2+}$ & $41 \mathrm{mg} \mathrm{L}^{-1}$ & $100 \%$ & PES & 10.0 & [102] \\
\hline & $105 \mathrm{mg} \mathrm{L}^{-1}$ & $\mathrm{Ni}^{2+}$ & $35 \mathrm{mg} \mathrm{L}^{-1}$ & $99.0 \%$ & PES & 10.0 & \\
\hline & $258 \mathrm{mg} \mathrm{L}^{-1}$ & $\mathrm{Cr}^{6+}$ & $43 \mathrm{mg} \mathrm{L}^{-1}$ & $95.0 \%$ & PES & 4.0 & \\
\hline & $0.05 \% \mathrm{w} / \mathrm{w}$ & $\mathrm{Cr}^{3+}$ & $10 \mathrm{mg} \mathrm{L}^{-1}$ & $100 \%$ & PSF & 7.0 & [98] \\
\hline & $0.05 \% \mathrm{w} / \mathrm{w}$ & $\mathrm{Cr}^{6+}$ & $10 \mathrm{mg} \mathrm{L}^{-1}$ & $100 \%$ & PSF & 4.0 & \\
\hline & $1 \mathrm{~g} \mathrm{~L}^{-1}$ & $\mathrm{Cd}^{2+}$ & $10 \mathrm{mg} \mathrm{L}-1$ & $98.5 \%$ & Ceramic & 7.5 & [99] \\
\hline
\end{tabular}


Table 3. Possible interactions of functional groups of biopolymers with metal ions.

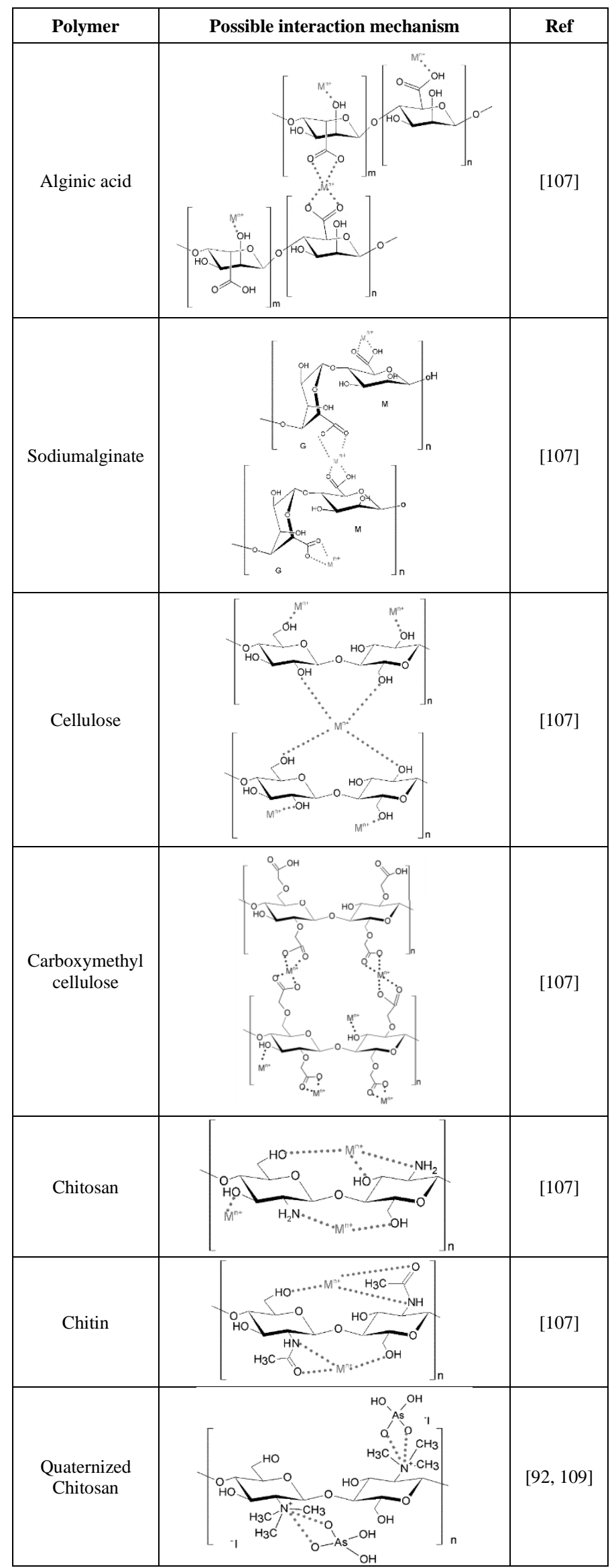

\section{OUTLOOK}

It is essential to develop new bio-based systems that can be applied for the removal of metal ions, and it is also necessary to study and scale upthe processes described previously in this review to find a solution to theenvironmental contamination generated every day.

Usingthis class of water-soluble biopolymers in combination with ultrafiltration membranes, it is possible to concentrate, separate, and remove metalions from wastewater.

These biopolymers are functionalized, therefore, can be applied in theremoval of a wide range of organic and inorganic pollutants and solve environmental problems.

\section{ACKNOWLEDGEMENTS}

The authors thank to FONDECYT (Grants No1190469 and No1191336).

\section{REFERENCES}

1. S.A. Alruman, A.F. El-Kott,M.A.Kehsk, Am. J. Environ. Sci. 6(3), 88 (2016)

2. D. Briggs, Br. Med. Bull, 68, 1 (2003)

3. S. Bibi,R.L. Khan,R.Nazir,P. Khan, H.U. Rehman, H.U, S.K. Shakir, S. Naz, M.A. Waheed, R. Jan, World Appl. Sci. J. 34(1), 15 (2016)

4. N. Khan,S.T. Hussain, A.Saboor, N. Jamila, K.S. Kim, Int. J. Phys. Sci,8(33), 1661 (2013)

5. M.J. Pawari, S.A.G.A.R. Gawande, Int. J. Eng. Res, 3(4), 773 (2015)

6. M.A. Khan, A.M. Ghouri, Researcher World: Journal of Arts, Science and Commerce, 2(2), 276 (2011)

7. S.M. Kamble, Int. J. Sci. Res, 4(1), 1 (2014).

8. F.D. Owa, Mediterr. J. Soc. Sci., 4(8), 65 (2013).

9. Y.C. Ho, K.Y. Show, X.X. Guo, I. Norli, F.A. Abbas, N. Morad, Industrial Waste, Intech, 1 (2012).

10. G. Banfalvi, Cellular Effects of Heavy Metals. London New York: Springer, Netherlands, 2011.

11. N. Herawati, S. Suzuki, K. Hayashi, I.F. Rivai, H. Koyoma, $B$. Environ.Contam. Tox, 64(1), 33 (2000).

12. U. Förstner, P. Mader, W. Salomons, Heavy Metals: Problems and Solutions. Germany: Springer-Verlag, Berlin, 1995.

13. Z.L. He, X.E. Yang, P.J. Stoffella, J. Trace Elem Med Bio, 19(2-3), 125 (2005).

14. J.H. Duffus, Pure Appl. Chem. 74(5), 793 (2002).

15. D. Sarma, S. M. Islam, K. S. Subrahmanyam, M. G. Kanatzidis, J. Mater. Chem. A, 4(43), 16597 (2016).

16. WHO, Chromium in drinking-water. Geneva, Switzerland, 2003.

17. I. Korus, K. Loska, Desalination. 247, 390 (2009).

18. A.J. Pedersen, Biomass Bioenerg, 25(4), 447 (2003).

19. B.L. Rivas, C. Espinosa, J. Sánchez, Polym. Bull. 76, 539 (2019).

20. D. Morales, O.Kusku, B.L. Rivas, M. Arda, N. Kabay, M. Bryjak, J. Chil. Chem. Soc. 64, 4432 (2019).

21. M. Palencia, B.L. Rivas, E. Pereira, A. Hernández, P. Prádanos. J. Membr Sci. 336, 128 (2009).

22. J. Sánchez, B.L. Rivas, J. Chil. Chem. Soc. 64, 4432 (2019).

23. Y. Tapiero, J. Sánchez, B.L. Rivas, J. Chil. Chem. Soc. 64, 4597 (2019).

24. B.L. Rivas, G.S. Canessa, S.A. Pooley, Makromol. Chem.-Macromol. Chem. Phys. 187, 71 (1986).

25. B.L. Rivas, S.A. Pooley, E.D. Pereira, R. Cid, M. Luna, M.A. Jara, K.E. Geckeler, J. Appl. Polym. Sci. 96, 222 (2005).

26. A.M. Sastre, F.J. Alguacil, F. J. Chem. Eng. J, 81, 109, (2001).

27. K.E. Geckeler, R. Zhou, B.L. Rivas, Angew. Makromol. Chem. 197, 107 (1992).

28. B.L. Rivas, S. A. Pooley, M. Luna. Macromol. Rapid Commun. 13, 905 (2000)

29. J. Sánchez, B. Butter, B.L. Rivas, L. Basáez, P. Santander. J. Appl. Electrochem. 45, 151 (2015).

30. E. Guibal, C. Milot, J. Roussy, Sep. Sci. Technol. 35, 1021 (2000).

31. J. Sánchez, B.L. Rivas, E. Nazar, M. Bryjak, N. Kabay, J. Appl. Polym. Sci. 129, 1541 (2013).

32. B.L. Rivas, G.S. Canessa, S.A. Pooley, Polym. Bull. 9, 417 (1983)

33. B.L. Rivas, I. Moreno-Villoslada, J. Membr. Sci. 178, 165 (2000)

34. B.L. Rivas, H.A. Maturana, E.D. Pereira, Angew. Makromol. Chem. 220, 61 (1994).

35. B.A.M. Al-Rashdi, D.J. Johnson, N. Hilal, Desalination. 315, 2 (2013).

36. J.A. Sánchez, B.L. Rivas, S. A. Pooley, L, Basaez, E. Pereira, I. PignotPaintrand, Ch. Bucher, G. Royal, E. Saint-Aman, J.-C. Moutet. Electrochim. Acta, 55, 4876 (2010). 
37. H. Ozaki, K. Sharma, W. Saktaywin, Desalination.144, 287 (2002).

38. K. Takagi, S. Miwa, Y. Yuki, React. Funct. Polym. 66, 1718 (2006).

39. B.L. Rivas, E.D. Pereira, I. Moreno-Villoslada, Progr. Polym. Sci. 28, 173 (2003).

40. B.L. Rivas, E.D. Pereira, M. Palencia, J. Sánchez, Progr. Polym. Sci. 36, 294 (2011).

41. K. Geckeler, G. Lange, H. Eberhardt, E. Bayer, Pure Appl. Chem. 52, 883 (1980).

42. B. Y. Spivakov, K. Geckeler, E. Bayer, Nature. 315 (6017), 313 (1985).

43. B. Nagel, H. Dellweg, L.M. Gierasch, Pure Appl. Chem,64(1), 143 (1992).

44. L.D. Fiorentina, D.E. Trigueros, A.N. Módenes, F.R. Espinoza-Quiñones, N.C. Pereira, S.T. Barros, O.A. Santos, Chem. Eng. J. 163(1-2), 68 (2010)

45. N.A. Cuizano, B.P. Llanos, A.E. Navarro, Rev. Soc. Quím. Perú, 75(4), 488 (2009)

46. N. Das, Hydrometallurgy, 103(1-4), 180 (2010)

47. A. Srinivasan, T. Viraraghavan, J. Environ. Manage., 91(10), 1915 (2010)

48. J.C. Muñoz Carpio, Tecno Lógicas, ISSN 0123-7799, 18, 34, 2015, 109-123 Universidad Nacional Mayor de San Marcos, 2007.

49. C. Lavado Meza, M. del R. SunKou, N.R. Arana, Rev. Soc. Quím. Perú, 78(1), 14 (2012).

50. M.K. Joshi, H.R. Pant, A.P. Tiwari, B. Maharjan, N. Liao, H.J. Kim, C.H. Park, C.S. Kim, Carbohydrate Polym, 136, 154 (2016).

51. N.V. Lukasheva, D.A. Tolmachev, Langmuir. 32(1), 125 (2016)

52. H. Luo, G. Xiong, C. Zhang, D. Li, Y. Zhu, R. Guo, Y. Wan, Mater. Sci. Eng. C, 49, 526 (2015).

53. D.A. Tolmachev, N.V. Lukasheva, Polym. Sci. Ser A, 56(4), 545 (2014)

54. A. Kovtun, D. Kozlova, K. Ganesan, C. Biewald, N. Seipold, P. Gaengler, W. H. Arnold, M. Epple. RSC Advances, 2(3), 870 (2012).

55. A. Salama, R.E. Abou-Zeid, M. El-Sakhawy, A. El-Gendy, Int. J. Biol. Macromol. 74, 155 (2015)

56. K. Bleek, A.Taubert, Acta Biomater. 9(5), 6283 (2013).

57. V. Sokolova, A. Kovtun, O. Prymak, W. Meyer-Zaika, E.A. Kubareva, E.A. Romanova, T.S. Oretskaya, R. Heumann, M. Epple, J. Mater. Chem. 17(8), 721 (2007)

58. T. Welzel, I. Radtke, W. Meyer-Zaika, R. Heumann, M. Epple, J. Mater. Chem.14, 2213 (2004).

59. F. Croisier, C. Jérôme, Eur. Polym. J, 49(4), 780 (2013).

60. M. Rinaudo, Prog. Polym. Sci., 31(7), 603 (2006).

61. N. Bhardwaj, S.C. Kundu, Biotechnol. Adv, 28(3), 325 (2010).

62. T. Dvir, O.Tsur-Gang, S. Cohen, Isr. J. Chem, 45(4), 487 (2005).

63. R. Jayakumar, D. Menon, K. Manzoor, S.V. Nair, H. Tamura, Carbohydr. Polym. 82(2), 227 (2010).

64. I. Aranaz, R. Harris, A. Heras, Curr. Org. Chem., 14(3), 308 (2010).

65. I. Aranaz, M. Mengíbar, R. Harris, I. Paños, B. Miralles, N. Acosta, G. Galed, A. Heras, Curr. Chem. Biol. 3(2), 203 (2009)

66. M. Kannan, M. Nesakumari, K. Rajarathinam, A.J.A.R. Singh, Adv. Biol. Res. 4(1), 10 (2010).

67. R. Riva, H. Ragelle, A. des Rieux, N. Duhem, C. Jérôme, V. Préat, Chitosan for biomaterials II, Springer, Berlin, Heidelberg, 2011.

68. X. Guo, Y. Wang, Y. Qin, P. Shen, Q. Peng, Int. J. Biol. Macromol, 162, $618(2020)$

69. G.K. Wasupalli, D. Verma. Int. J. Biol. Macromol. 114, 10 (2018).

70. S. Islam, M.A.R. Bhuiyan, M.N. Islam, J. Polym. Env. 25, 854 (2007)

71. S. Gorgieva, R. Vorgrinĉiĉ, V. Kokol, J. Polym. Environ. 27, 318 (2019)

72. R. Belalia, S. Grelier, M. Benaissa, V. Coma, J. Agric. Food Chem. 56(5), 1582 (2008).
73. Y. Huang, X. Fen, J. Membr. Sci, 586, 53 (2019).

74. M. Mulder, Basic Principles of Membrane Technology, Kluwer Academic, 1991.

75. V. Snceyink, D. Jenkins, Water Chemistry, John Wiley, 1980.

76. T. Radeva, Physical Chemistry of Polyelectrolytes, Marcel Dekker, 2001.

77. M. Palencia, B.L. Rivas, E. Pereira, A. Hernández, P. Prádanos, J. Membr Sci. 336, 128 (2009)

78. F. Liu, N.A. Hashim, Y. Liu, M.M. Abed, K. Li, J. Membr. Sci, 375(1-2), 1 (2011).

79. K.E. Geckeler, E. Bayer, B.Y. Spivakov, V.M. Shkinev, G.A. Vorob'eva Anal. Chim. Acta, 189, 285 (1986).

80. B.L. Rivas, B.F. Urbano, J. Sánchez, Front. Chem. 6, 320 (2018).

81. M. Palencia, J. Chem. 1 (2015). https://doi.org/10.1155/2015/965624

82. S. Gokila, T. Gomathi, P.N. Sudha, S. Anil, Int. J. Biol. Macromol 104, 1459 (2017).

83. G. Sharma, M. Naushad, A.H. Al-Muhtaseb, A. Kumara, M.R. Khan, S. Kalia, Shweta, M. Bala, A. Sharma, Int. J. Biol. Macromol. 95, 484 (2017).

84. I.P. Fernando, K.K. Sanjeewa, S. Kim, J. Lee, Y. Jeon, Int. J. Biol. Macromol.106, 330 (2018).

85. C. Çifci, Ş. Polat, J. Macromol. Sci A, 46(7), 682 (2009).

86. A. Maureira, B.L. Rivas, Eur. Polym. J. 45(2), 573 (2009).

87. D.W. O’Connell, C. Birkinshaw, T.F. O’Dwyer, Bioresour. Technol., 99(15), 6709 (2008).

88. L.Y. Wang, M.J. Wang, ACS Sustain. Chem. Eng., 4(5), 2830 (2016).

89. M.A. Barakat, E. Schmidt, Desalination, 256(1-3), 90(2010).

90. V. Konovalova, I. Kolesnyk, O. Ivanenko, A. Burban, Environ. Prot. Eng, 21(1), 39 (2018).

91. B. Lam, S. Déon, N.M. Crini, G. Crini, P. Fievet, J. Clean. Prod, 171, 927 (2018).

92. J. Sánchez, B. Butter, S. Chavez, L.Riffo, L. Basáez, B.L. Rivas, Desalination Water Treat. 57(52), 25161 (2016).

93. S. Saha, M.Zubair, M.A.Khosa, S. Song, A.Ullah, J. Polym. Environ. 27, 1389 (2019).

94. I. Anastopoulos, A.Bhatnagar, D.N.Bikiaris, G.Z. Kyzas, Int. J. Mol. Sci., 18(1) 114, (2017).

95. V. Zargar, M.Asghari, A.Dashti, Chem. Bio. Eng. Rev. 2(3), 204 (2015).

96. L. Zhang, Y. Zeng, Z. Cheng, J. Mol. Liq. 214, 175 (2016).

97. M. Vakili, S. Deng, G.Cagnetta, W. Wang, P.Meng, D. Liu, G. Yu, Sep. Purif. Technol. 224, 373 (2019).

98. M.K. Aroua, F.M. Zuki, N.M. Sulaiman, J. Haz.Mat., 147, 752 (2007)

99. J. Llorens, M. Pujolà, J. Sabaté, J. Membr. Sci. 239, 173 (2004)

100.L. Toledo, B.L. Rivas, Polym. Bull. 72(6), 1365 (2015)

101.S. Deón, J. Deher, B. Lam, N. Crini, G. Crini, P. Fievet, Ind. Eng. Chem. Res. 56(37), 10461 (2017).

102.E. Kavitha, A.Sowmya, S. Prabhakar, P. Jain, R. Surya, M.P. Rajesh, Int. J. Biol. Macromol. 132, 278 (2019)

103.D.J. Ennigrou, M.B.S. Ali, M. Dhahbi, Desalination, 343, 82 (2014)

104.P. Cañizares, A. Pérez, R. Caramillo, R. Mazarro, J. Membr. Sci. 320, 520 (2008)

105.R. Molinari, P. Argurio, T. Poerio, Macromol. Symp. 235, 206 (2006)

106.P. Cañizares, Á. Pérez, R. Camillo, Desalination. 144, 279, (2002)

107.B.L. Rivas, E. Pereira, A. Maureira, Polym. Int. 58(10), 1093 (2009)

108.J. Sánchez, L. Toledo, B.L. Rivas, N. Rivera, E. Muñoz, J. Chil. Chem. Soc. 58(4), 1986 (2013). 